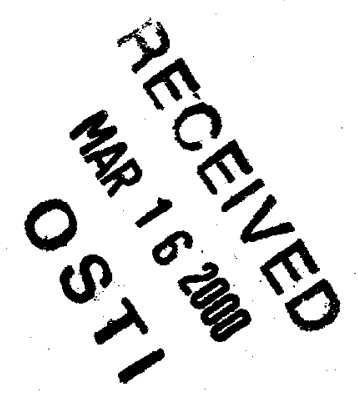

\title{
Debt Swapping as a Tool for Economic and Social Stabilization in Russia's Closed Nuclear Cities
}

(Briefing Paper)

James L. Fuller

K. Mark Leek

January, 2000

Prepared for the U.S. Department of Energy under Contract DE-AC06-76RLO 1830 


\title{
DISCLAIMER
}

This report was prepared as an account of work sponsored by an agency of the United States Government. Neither the United States Government nor any agency thereof, nor Battelle Memorial Institute, nor any of their employees, makes any warranty, express or implied, or assumes any legal liability or responsibility for the accuracy, completeness, or usefulness of any information, apparatus, product, or process disclosed, or represents that its use would not infringe privately owned rights. Reference herein to any specific commercial product, process, or service by trade name, trademark, manufacturer, or otherwise does not necessarily constitute or imply its endorsement, recommendation, or favoring by the United States Govemment or any agency thereof, or Battelle Memorial Institute. The views and opinions of authors expressed herein do not necessarily state or reflect those of the United States Government or any agency thereof.

\author{
PACIFIC NORTHWEST NATIONAL LABORATORY \\ operated by \\ BATTELLE \\ for the \\ UNITED STATES DEPARTMENT OF ENERGY \\ under Contract DE-AC06-76RLO 1830
}

Printed in the United States of America

Available to DOE and DOE contractors from the

Office of Scientific and Technical Information, P.O. Box 62, Oak Ridge, TN 37831;

prices available from (615) 576-8401.

Available to the public from the National Technical Information Service, U.S. Department of Commerce, 5285 Port Royal Rd., Springfield, VA 22161 


\section{DISCLAIMER}

\section{Portions of this document may be illegible in electronic image products. Images are produced from the best available original document.}




\section{Debt Swapping as a Tool for Economic and Social Stabilization in Russia's Closed Nuclear Cities \\ (Briefing Paper)}

James L. Fuller

K. Mark Leek

January; 2000

Prepared for the U.S. Department of Energy under Contract DE-AC06-76RLO 1830

Pacific Northwest National Laboratory

Richland, Washington 99352 


\title{
Debt Swapping as a Tool for Economic and Social Stabilization in Russia's Closed Nuclear Cities
}

\author{
(Briefing Paper)
}

The next great issue on the Russian landscape will be management of its foreign debt. In the near future the United States will be called upon to lead an international program of debt restructuring to assist Russia in overcoming the burden of its debt trap. With debt service obligations equal to $50 \%$ of 1999 revenues, Russia has virtually no chance of sustaining a program of economic recovery without debt relief (Hardt, 1999).

With some form of debt restructuring a forgone conclusion, Russia, the United States, and world community have a vital stake in searching for creative ways to transform the inevitability of debt restructuring into something of value and constructive to Russia and the problems it faces. This was the rationale behind debt-for-nature swaps which emerged in the early 1980s in Latin American and Eastern Europe as a means of relieving developing nations of their crippling foreign debt. Debt-for-nature swaps served both domestic and international needs by converting a portion of foreign debt, often at steep discounts, into local currency that was then used to fund programs to preserve the environment. The debt swap mechanism provides the prospect of getting something of real value where nothing is expected.

The Pacific Northwest National Laboratory (PNNL) has proposed to use the same model to synergistically capitalize defense threat reduction activities and environmental remediation within Russia's closed nuclear cities. Preventing the emigration of nuclear technology, expertise, and hardware from these cities to subnational groups and countries of proliferation concern is one of the world's foremost pressing problems. It is in the best national security interest of the United States to assist Russia in overcoming the legacy of the Cold War by helping to address the catastrophic environmental and public health effects of nuclear production that negatively impact economic stabilization.

\section{Summary}

The following "briefing paper", is intended as a companion piece to the accompanying white paper of the same title. The briefing paper was originally drafted for senior Department of Energy officials to familiarize them with the PNNL debt swap proposal in anticipation of Secretary Richardson's planned meeting with Minister Adamonv in Denver in late 1999. In a succinct manner the briefing paper describes the key elements of the PNNL proposal, and the three fundamental models to effect debt conversion: official debt forgiveness, commercial debt purchase on the secondary market, and commercial debt donation. The paper provides an overview of steps that have been taken to date to advance the project.

\section{Key Elements of PNNL Debt Swap Proposal:}

Parallel Cooperative Program: By paralleling efforts to draw down the Russian nuclear weapons complex with a program to address pressing closed city ecological and health issues, alternative scientific employment opportunities become available for near-term 
economic stabilization. As in Richland-Hanford, this also amounts to a strategic investment not only by making new jobs available to nuclear workers, but also in making the city and region more acceptable for commercial development.

Model City-Ozersk: Richland-Hanford, site of the Pacific Northwest National Laboratory, is the closest parallel in past development and future prospects to OzerskMayak. Moreover, PNNL has established close working relations with city officials in Ozersk. Successes with this model are likely to be applicable to other closed nuclear cities.

Funding: A very important dimension of this proposal is that no new significant U.S. appropriated funds should be required. Russian debt, owed to foreign investors and creditor nations, can be converted through established mechanisms to rubles for use in improving economic opportunities and environmental conditions in Ozersk and elsewhere. These funds will produce a strong multiplrer effect in attracting and leveraging tax funds, local contributions in-kind, international financial institution support, foundation funds, etc.

\section{Models of Debt Swapping:}

Debt-for-nature swaps were conceived in 1984 by the World-Wide Fund for Nature (Lovejoy, 1984). In these exchanges, a certain amount of foreign debt is cancelled or forgiven in return for local currency which is applied to an environmental project. Based on this success, dept swaps have also been applied to a variety of fields, including debt-for-health, debt-forcharity, debt-for-child development, and debt-for-sustainable development (Thapa, 1998).

There are three fundamental models to effect debt conversion. These are:

- Official Debt Forgiveness. In this model, creditor nations, working through the Paris Club, agree to forgive a portion of a debtor nation's outstanding bilateral debt. A portion of bilateral debt, with terms agreed upon by the Paris Club, is then converted into domestic currency to fund domestic programs. In certain circumstances individual members may go beyond these terms.

- Polish-Paris Club Debt-for-Nature Exchange. In March 1991, Paris Club members agreed to forgive fifty percent of Poland's US\$35 billion external debt. The debt swap agreement between the Polish government and its creditors focused mostly on environmental cleanup programs. The Paris Club authorized members to forgive an additional ten percent of Polish debt through debt-for-nature swaps. The U.S. government went beyond these provisions by agreeing to reduce bilateral debt by seventy percent.

- Commercial Debt Purchase on the Secondary Market. In this model an international nongovernmental organization (INGO) purchases commercial debt on the secondary market, often at a steep discount. Typically the INGO negotiates with the debtor nation to exchange the debt note into local currency to be used to purchase interest earning bonds to support local programs.

- Ecuadorian Debt-for-Nature Swap. In 1987, the World Wildlife Fund purchased \$1 million in Ecuadorian debt and assigned the debt to an Ecuadorian environmental 
NGO. The Ecuadorian government issued bonds which paid interest in local currency into an environmental fund. Proceeds of the fund were distributed to the local NGO which used the money to finance protection of nature reserves.

- Commercial Debt Donation. In this model banks donate commercial debt that they do not expect to recover to INGOs which in turn negotiate with the debtor nation to convert the debt note into local currency. Debt swaps allow banks to realize a return on investment where otherwise there would be none through provisions in the U.S. tax code that allow banks to write-off charitable contributions to not-for-profit organizations.

- In 1992, J.P. Morgan donated US\$11.5 million in Bolivian bank debt to fund conservation and environmental programs. The donation, organized by The Nature Conservancy and the World Wildlife Fund, represented the entire amount of J.P Morgan's Bolivian debt.

\section{Current Status of Development:}

Actions to date have centered on conceptual development of the debt swap model and its possible application to Russian debt relief, and obtaining the support of key stakeholders in the Department of Energy, Minatom, and city of Ozersk. Among these actions:

- In early October, 1999, the Mayor the Ozersk, Sergei Chernyshov, and a city delegation visited PNNL to learn more about strategies of economic diversification based on the Richland-Hanford model. During this time, ecological debt conversion was proposed as a joint initiative by the U.S. (PNNL) side.

- In mid-October, 1999, Rose Gottemoeller, head of DOE-NN, was briefed on the debt swap concept and expressed strong interest for continued PNNL involvement and development of the concept.

- In mid-October, 1999, Sergei Chernyshov briefed Minatom Minister Adamonv on the concept and potential role of Ozersk as a model city. Minister Adamonv expressed great interest and encouraged Ozersk involvement. Mayor Chernyshov has provided PNNL with a prioritized list of environmental problems negatively impacting public health and economic stabilization in Ozersk.

- In mid-October, 1999, the office of Congressman Norm Dicks was briefed on the PNNL proposal. Congressman Dicks is strongly supportive and is keenly interested in cooperative efforts with Russian cities, especially given the fact that no new significant appropriations will be required. Through the auspices of his office, a key U.S. government Russian economist (Dr. John Hardt, Congressional Research Service) is advising this effort. Dr. Hardt briefed congressman Dicks on CRS findings on December $9,1999$.

- In mid-December, 1999, a teleconference occurred between technical teams from PNNL and Mayak-Ozersk to allow the PNNL team to better understand the technical dimensions and scale of the Ozersk-Mayak ecological proposals submitted for consideration as part this initiative. The Ozersk-Mayak team was receptive to meeting in Ozersk between Mayak and PNNL technical counterparts to discuss further the proposal initiatives. 


\section{Suggested Topics of Discussion:}

These are suggested topics for senior Department of Energy officials to consider in discussing the proposal with their Russian counterparts.

- Statement of awareness and support of the proposal by Secretary Richardson and Assistant Secretary Gottemoeller.

- Support that both Minatom and DOE keep abreast of proposal developments.

- Indicate that DOE will guide PNNL in responding to the Ozersk list of environmental remediation priorities.

- Note that PNNL will assist DOE in approaching the Department of Treasury and other U.S. departments, as well as Congress, in proposing a project based on conversion of official debt. Note that PNNL is forming a blue ribbon advisory board to assist with the conversion of Russian commercial debt.

- Express support for a meeting between PNNL and Mayak technical counterparts in Ozersk to discuss further ecological proposal initiatives. 


\section{References}

Hardt, J.P. , 1999, Russia's Economic Policy Dilemma and U.S. Interests. CRS Report for Congress, Library of Congress, Washington D.C.

Lovejoy, T.E., 1984, October 4, Aid Debtor Nations' Ecology, The New York Times, New York.

Thapa, B., 1998, Debt-for-Nature Swaps: an Overview, International Journal of Sustainable Development and World Ecology, 5, 249-262. 


\section{Appendix: List of Ecolological Projects Proposed by Mayak, City of Ozersk, Chelyabinsk Region}

\section{PNNL Note:}

The following is a list that was provided by the City Administration of the City of Ozersk on October 27, 1999 at the request DOE/NN and PNNL. It is indicative of the projects the City would like to be considered in conjunction with debt-for-nature and debt-for-health initiatives connected with economic diversification and social stabilization of this closed nuclear city. Such initiatives are being pursued consistent with U.S. nonproliferation and national security goals. The establishment of this list to share with the U.S. was approved directly by Minatom Minister Adamov on October 14, 1999, at the request of Mayor Sergei Chernyshov. The list was evidently established with support from the Mayak Production Association (MPA). The items on the list are longstanding issues, the funding for which has been requested from Minatom and the Russian Federal Government with little if any positive response.

\section{Stabilization of water balance of Techensky water cascade (several lakes connected on different levels)}

During the initial period of the activity of Mayak, disposal of all low-level as well as some mid-level activity waste was done into the Teche. River. As a result, the riverbed was polluted entire length of river. The main part of radioactive nuclides was deposited into the upper part of the river. In order to prevent additional deposition of radionuclides into the river, the Techen cascade consisting of 4 water bodies was created. The present cascade conditions are about $400 \times 10^{6}$ cubic meters of water polluted up to $10^{-7}$ curies/liter on long-lived radionuclides. Because of the fact that the system of the water bodies is static, and the water level in the last of the water bodies is close to maximum projected level, there is a danger of the overflowing the system and discharge of polluted water into the Teche river. Work on the Teche water body cascades includes:

1.1 Construction of water treatment plant for the water deposited from the production site

1.2 Reconstruction of ash depository at the Argayachskaya electrical plant

1.3 Transfer of above mentioned plant to burn gas

\section{Reprocessing of Accumulated High-level waste}

About 400 million curies radioactive high-level waste has been accumulated at the plant and in the form of nitric acid, as well as hydro-acid depositories. We are planning use of specialized technologies, for instance, a technology of fractioning as well as reprocessing of accumulated waste into glass-like matrix. Within this program, we are 
also planning to create "hot cells" for solidifying of fractions of long-lived radionuclides as well as transuranics.

\section{Liquidation (Getting Rid of ) of Water Depositories for Liquid Radioactive Waste Similar to Karachay Water Depository}

The Karachay water depository is mid-level waste depository. It contains around 120 million curies of long-lived fission products.

The scope of work includes:

3.1 Covering the surface of the water body with granite

3.2 Creation of a site for processing and solidifying of mid-level waste

3.3 Creation of glass-like bottom for the water bed for contaminated groundwater

3.4 Creation of town of Novogorny water supply system

\section{Deactivation and Conservation of Building, and Facilities taken out of operation,} including uranium graphite reactors

Mayak includes a number of buildings, including uranium graphite reactors, which at present time are not operating. The scope of work includes making them safe for personnel and environment.

\section{Reconstruction of Old Burial Grounds for Solid Radioactive Waste}

Within the previous years, Mayak has accumulated over 500 tons of solid radioactive waste, the bulk of which was disposed of into the grounds of the trench type. The number of those burial grounds at this moment is over 200 . The goal is to bring those burial grounds into safe state.

\section{Creation of Solid Radioactive Waste Compacting Site and A Ground for Its Long-term Storage}

(PNNL note: This item most likely refers to a low-level solid waste facility similar to the commercial site at Hanford. We have asked for Russian clarification, 1027/99) 


\section{Deactivation of Contaminated Areas}

In 1957, as a result of the explosion of one of the liquid waste tanks, a portion of the Ural Region was contaminated. The bulk of the radioactive elements were dispersed within production site of Mayak. To reduce the secondary transfer of radioactive elements, deactivation of this portion of the production site is needed because of highlevel contamination.

A portion of above-mentioned projects is being financed by the Federal Program "Social and Radiation Rehabilitation of the Population and Areas of the Ural Region Which were Contaminated as Result of the Activity of the Production Site of Mayak as of the Year 2000." At present, the volume of the financing of this similar program is being negotiated for period present-2010. 